\title{
Differences in aquatic microcrustacean assemblages between temporary and perennial springs of an alpine karstic aquifer
}

\author{
Nataša Mori* and Anton Brancelj \\ National Institute of Biology, Večna pott 111, Ljubljana, 1000, Slovenia
}

Abstract: Microcrustacean (Copepoda, Ostracoda) assemblages were investigated at the interface of the vadose and phreatic zones in the alpine karstic aquifer from the Julian Alps in Slovenia (SE Europe). Two temporary and one perennial karstic outlets were sampled by filtering the water several times over 2 years. Concurrently, benthos from the mouth of a perennial spring and from an adjacent spring brook were collected. Altogether 24 microcrustacean species were recorded. The spatial and temporal variation in drift densities and species composition was high indicating complex groundwater hydrological pathways being dependent on precipitation regime. Non-metric Multidimensional Scaling (NMDS) clearly separated drift samples from temporary springs and other sample groups (drift in perennial spring, spring mouth and spring brook benthos). ANOSIM revealed statistically significant differences between all sample groups (Diacyclops zschokkei, Elaphoidella phreatica and Mixtacandona sp. B contributed over $50 \%$ to the observed differences among sample groups. Three species (Nitocrella sp., Speocyclops infernus, Lessinocamptus pivai), known to be typical epikarst species, were collected only in the drift from one temporary spring (T2). Mao Tau species accumulation curves did not reach asymptote for the drift from temporary springs, but did for the drift from perennial spring, and for the spring mouth and the spring brook benthos. The results on drift composition indicated the variation in the origin of the water discharging at the interface of vadoze and phreatic zones depending greatly on water level conditions, while the drift densities were higher in the water presumably discharging from phreatic zone (perennial spring and temporary springs during low water levels).

Keywords: Julian Alps; alpine karst; groundwater; drift; Copepoda; Ostracoda

Received 6 February 2013; Revised 31 July 2013; Accepted 12 September 2013

Citation: Mori N. and Brancelj A., 2013. Differences in aquatic microcrustacean assemblages between temporary and perennial springs of an alpine karstic aquifer. International Journal of Speleology, 42 (3) 257-266. Tampa, FL (USA) ISSN 0392-6672 http://dx.doi.org/10.5038/1827-806X.42.3.9

\section{INTRODUCTION}

The alpine karst, formed in the high mountain areas, is characterized by colder conditions due to high altitude, by restricted vegetation, seasonal snow and snow melt, and presence of past and present glaciers (Smart, 2004). Alpine karstic aquifers are invaluable reservoirs of drinking water and an important potential source for the future as well (Petrič, 2004). In karstic areas, the water from rainfall and snow melt flows through highly heterogeneous flow paths formed in the fractured rock (vadose zone with epikarst) until it reaches a saturated or phreatic zone (Gibert et al., 1994; Williams, 2008). At the contact zone between the fractured and less fractured rock or between permeable and impermeable layers, the groundwater discharges into temporary or perennial springs, which in the alpine areas usually occur at the foots of steep walls (Gams, 2003).

Karstic aquifers are inhabited by diverse hypogean aquatic fauna. Many of the hypogean species are endemic, occurring only in the particular locality or region (Culver and Sket, 2000; Gibert and Deharveng, 2002). Intensive studies of hypogean aquatic fauna over the central and southern Europe demonstrated that one of the richest regions in the number of stygobionts (i.e. strictly hypogean species) is the karstified peri-Mediterranean region and a wider Dinaric region (SE Europe) (Sket, 1999; Dole-Olivier et al., 2009b). Less information exists regarding hypogean aquatic fauna from the Alpine areas in Europe (Stoch, 2000; Sambugar et al., 2008; Cristian and Spöt1, 2010; Papi and Pipan, 2011). A study from the northern Italian Alps, where high altitude caves were sampled, demonstrated that stygobionts are not as rare as expected for this region (Sambugar et al., 2008). Possible reasons for that could be either re-colonization following the retreat of Würmian glaciers, or their survival in the deep aquifer during the Quaternary glaciations (Sambugar et al., 2008).

Karstic aquifers are geomorphologicaly and hydrologicaly highly heterogeneous and difficult to 
access (Kaufmann, 2003). Fauna of the epikarst and vadose zone is mostly investigated directly by entering the caves and less often by applying boreholes or monitoring wells (Malard et al., 1996; Hahn and Fuchs, 2009), filtering water at karstic outlets (i.e. collecting invertebrate drift) (Leruth, 1939; Rouch, 1968; Rouch et al., 1968; Gibert, 1986; Vervier and Gibert, 1991) or sampling the benthos in the karstic springs (Galassi et al., 2009b). In caves, investigations are usually focused on selected hypogean habitats that are either cave streams (Sket and Bole, 1981; Fong and Culver, 1996; Schneider and Culver, 2004), puddles and pools filled with percolating water (Brancelj, 2002; Fišer and Zagmeister, 2009), or trickles of percolating water (Pipan and Brancelj, 2004; Sket et al., 2004). In the last decade, regional assessment of hypogean biodiversity using a hierarchical approach was carried out across Europe that also made a comparison of species richness between the vadose and phreatic zone of the same karstic aquifers possible (PASCALIS project; Dole-Olivier et al., 2009b; Galassi et al., 2009b; Stoch et al., 2009). At a regional scale, historical variables (glaciations and the age of geological formations), altitude and geology (pore size) primarily determined the hypogean community composition and species richness (Dole-Olivier et al., 2009a). A comparison of the vadose and phreatic zones revealed higher regional species richness in the former (Dole-Olivier et al., 2009b; Galassi et al., 2009b; Galassi et al., 2013), most probably due to higher habitat heterogeneity and habitat fragmentation.

The objective of this study was to investigate differences between microcrustacean assemblages from two temporary and one perennial karstic outlets located at the interface of the vadose and phreatic zones of an alpine karstic aquifer. The study was carried out at a scale of a single karstic aquifer where filtering of the spring water and collecting invertebrate drift was conducted several times over two years during different hydrological conditions. Species richness and composition were expected to be affected by hydrological conditions during the sampling, when the springs will be fed either by stored water from the phreatic zone during low-water level conditions, by the water flowing from the epikarst and vadose zones or by the mixed water discharging from both zones during high-water level conditions. Concurrently, the sampling of the benthos from the adjacent spring mouth and the spring brook was carried out simultaneously with an objective to compare both sampling methods (drift versus benthos) in order to assess aquatic hypogean diversity and species composition. It was predicted that filtering of spring water will provide a better estimate of hypogean species richness than collecting the benthos from the spring mouth due to the fact that in the first case the fauna is collected directly from the water discharging from the aquifer while the sampling of benthos encompasses all the species living in the benthos, including surface species that normally never colonize hypogean habitats.

\section{Study site}

\section{MATERIALS AND METHODS}

The Lipnik spring complex is situated in the Julian Alps (NW Slovenia) which are part of the Southern Limestone Alps. The water discharges at the bottom of steep slopes of the Pokljuka plateau (altitude of $1300 \mathrm{~m}$ a. s. 1.), and continues as a short stream to the Radovna river, flowing in the upper Sava river catchment (Fig. 1). The karstic aquifer of the Pokljuka is composed mainly of massive limestone and thickgrained dolomite of the Triassic age (Buser, 1987) and is fed from the surface by diffusive recharge only.

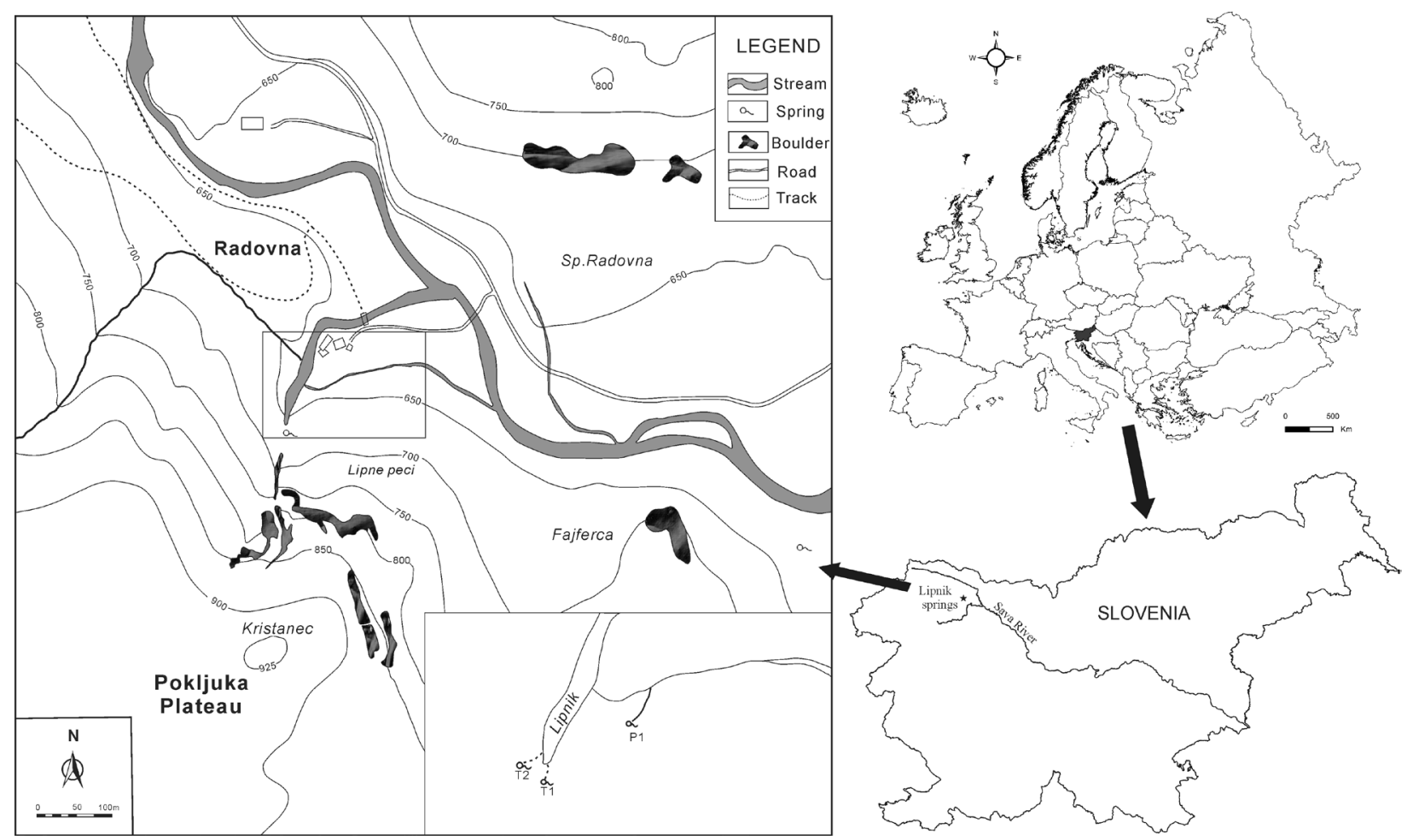

Fig. 1. Location of the study area and sampling sites. The exact position of the spring outlets is presented in the enlargement at the bottom right side: T1, T2 - temporary springs; P1 - perennial spring. 
The water discharges through two temporary springs (T1 - 46 $23^{\prime} 03^{\prime \prime} \mathrm{N}, 1^{\circ} 01^{\prime} 36^{\prime \prime} \mathrm{E}$; T2 - 46 $23^{\prime} 04^{\prime \prime} \mathrm{N}$, $14^{\circ} 01^{\prime} 35^{\prime \prime} \mathrm{E}$, altitude $692 \mathrm{~m}$ a.s.1.) and one perennial spring $\left(46^{\circ} 23^{\prime} 05^{\prime \prime} \mathrm{N}, 14^{\circ} 01^{\prime} 38^{\prime \prime} \mathrm{E}\right.$, altitude $665 \mathrm{~m}$ a. s. 1) situated within a distance of $60 \mathrm{~m}$ and along altitudinal difference of $30 \mathrm{~m}$. In 2009 and 2010, the annual precipitation in the area was 2204 and 2277 $\mathrm{mm}$, respectively (the Radovna meteorological station; Environment Agency of RS). The overall discharge of the system is highly variable ranging from 0.41 to 1.51 $\mathrm{m}^{3} \mathrm{~s}^{-1}$ (data from 2008; Environment Agency RS). The water temperature of the perennial spring measured by data logger continuously from June 2009 to June 2010 was between 6.4 and $7.3{ }^{\circ} \mathrm{C}$. The age of the spring water was estimated to be around 3.8 years (Kanduč et al., 2012).

\section{Sampling methodology}

Filtering nets (circle opening, diameter $0.2 \mathrm{~m}$, mesh size $100 \mu \mathrm{m}$, net length $1 \mathrm{~m}$ ) were placed in the mouths of three springs ( $\mathrm{P}$ - perennial; T1, T2 - temporary) for 24 hours during three seasons (spring, summer, autumn) over two years $(2009,2010)$ (Fig. 2). The data from the last sampling campaign (Oct 2010) for the two temporary springs $(\mathrm{T} 1, \mathrm{~T} 2)$ were not included in the data analyses due to accidental dislocation of the nets during the filtering. Occasionally, the water from the two temporary springs discharged up to 60 $\mathrm{m}$ downstream from the usual site placed at the foot of steep rock wall as shown on Fig. 1. During the extreme low flow conditions the water from temporary springs discharged at the same altitude as the water from the perennial spring. Concurrently with drift sampling, the benthos from the perennial spring mouth (SM) and from the spring brook (SB) at the site approximately $10 \mathrm{~m}$ downstream from the spring mouth were sampled by a kick sampling method. A substrate of approximately $0.04 \mathrm{~m}^{2}(20$ x $20 \mathrm{~cm})$ was kicked by foot for $1 \mathrm{~min}$ and a hand net (mesh size $100 \mu \mathrm{m}$ ) was used to collect the animals. Additionally, larger stones were picked and washed out into the hand net.

Biological samples were preserved in $70 \%$ ethanol and taken to the laboratory for further processing. Prior to collecting the biological samples, oxygen (WTW Multiline P4, CellOx 325), temperature and conductivity (WTW Multiline P4, TetraCon 325) were measured in the perennial spring mouth. The water levels and flow velocities were measured using an OTT ADC flow meter on every sampling occasion and each spring.

For the laboratory analyses, $250 \mathrm{ml}$ of water was collected in polyethylene bottles (for the measurements of $\mathrm{pH}$, alkalinity, total nitrogen and total phosphorus) from the mouth of the perennial spring. Sample aliquots collected for cation and anion analyses were passed through a $0.20 \mu \mathrm{m}$ nylon filter into High Density Polyethylene (HDPE) bottles and kept refrigerated until analyzed.

\section{Laboratory analyses}

In the laboratory, $\mathrm{pH}$ was measured using a WTW pH 540 GLP, with a TetraCon 325 probe. Alkalinity was determined using titration after Gran, and was expressed as $\mathrm{CaCO}_{3}$ equivalent per liter. Total nitrogen and total phosphorus were measured spectrophotometrically (Clesceri et al., 1998). Cations $\left(\mathrm{Na}^{+}, \mathrm{K}^{+}, \mathrm{Ca}^{2+}, \mathrm{Mg}^{2+}\right)$ and anions $\left(\mathrm{SO}_{4}{ }^{2-}\right.$, $\mathrm{PO}_{4}^{3-}, \mathrm{NO}_{3}^{-}$) were measured by ion chromatography (Metrohm, 761 Compact IC). Biological samples were sorted, the animals counted and microcrustaceans identified to the species level using identification keys (Einsle, 1993; Janetzky et al., 1996; Meisch, 2000). The number of the animals in drift samples was standardized to the number of specimens per $1000 \mathrm{~m}^{3}$, where the absolute numbers were divided or multiplied by a correction factor obtained from the actual volume of filtered water.

\section{Data analyses}

The differences in microcrustacean species composition were investigated by non-metric multidimensional scaling (NMDS) based on a distance matrix computed with a Bray-Curtis similarity index as a distance measure. Prior to the analysis, the data were standardized by expressing the number of specimens of each species as a percentage of total specimens in the sample. SIMPER (Similarity Percentage) was carried out to calculate which taxa are primarily responsible for an observed difference between groups of samples. The overall significance of the difference was assessed by ANOSIM (Analysis of Similarity analyses). The analyses were performed by using the software PAST version 1.95 (Hammer et al., 2001).

The sample-based rarefaction curves (Sobs or Mao Tau) were calculated using analytical formulas to perform a quantitative comparison between assemblages (Gotelli and Colwell, 2001; Colwell et al., 2004; Mao et al., 2005). The species accumulation curves were estimated for drift samples from the temporary and perennial springs and for the benthic samples from spring the mouth and the spring brook, respectively. The total species richness was calculated by using the equation Chao 2 applied on the incidence-based data where the number of uniques and duplicates are considered (Chao, 1987). The calculations were computed using EstimateS (Version 8.2, R. K. Colwell, http://purl.oclc.org/estimates) (Colwell, 2009).

\section{RESULTS}

\section{Physicochemical characteristics of the spring water}

Water temperature was $6.7 \pm 0.1^{\circ} \mathrm{C}$ and conductivity $247 \pm 63 \mu \mathrm{S} \mathrm{cm} \mathrm{cm}^{-1}$ (Table 1). $\mathrm{pH}$ ranged from 7.5 to 8.0, alkalinity from 2411 to $3050 \mu \mathrm{eq} \mathrm{l}^{-1}$ of $\mathrm{HCO}_{3}^{-}$ and oxygen concentration from 10.4 to $11.8 \mathrm{mg}^{-1}$. $\mathrm{NO}_{3}{ }^{-}$concentration was from 1.8 to $2.5 \mathrm{mg} \mathrm{l}^{-1}$ while $\mathrm{PO}_{4}^{3-}$ was under a detection limit and not presented in Table $1 . \mathrm{Ca}^{2+}$ prevailed in the water $(55.7-73.3 \mathrm{mg}$ $\left.1^{-1}\right)$ in comparison to $\mathrm{Mg}^{2+}\left(2.8-4.4 \mathrm{mg} \mathrm{1}^{-1}\right)$ and mean concentrations of $\mathrm{Na}^{+}, \mathrm{K}^{+}$, and $\mathrm{SO}_{4}^{2-}$ ions were $1.4,0.2$, and $2.5 \mathrm{mg} \mathrm{l}^{-1}$ respectively. The mean total nitrogen and mean total phosphorus in the spring water were $0.9 \pm 0.2 \mathrm{mg}^{-1}$ and $12.5 \pm 7.9 \mu \mathrm{g}^{-1}$, respectively. 
Table 1. Main physical and chemical characteristics of the water from the perennial spring (P1). Concentrations of $\mathrm{PO}_{4}{ }^{3-}$ were below detection limit and are not listed in the table.

\begin{tabular}{|c|c|c|c|c|c|c|c|c|c|c|c|c|c|}
\hline Date & $\begin{array}{c}\text { Temp } \\
{ }^{\circ} \mathrm{C}\end{array}$ & $\begin{array}{c}\text { Cond } \\
\mu \mathrm{S} \mathrm{cm}^{-1}\end{array}$ & $\mathrm{pH}$ & $\begin{array}{l}\text { Alkal } \\
\text { heq }\left.\right|^{-1}\end{array}$ & $\begin{array}{c}\mathrm{O}_{2} \\
\mathrm{mgl}^{-1} \\
\end{array}$ & $\begin{array}{l}\mathrm{NO}^{3}- \\
\mathrm{mgl}^{-1} \\
\end{array}$ & $\begin{array}{l}\mathrm{Ca}^{2+} \\
\mathrm{mg} \mathrm{l}^{-1} \\
\end{array}$ & $\begin{array}{l}\mathrm{Mg}^{2+} \\
\mathrm{mg} \mathrm{l}^{-1} \\
\end{array}$ & $\begin{array}{l}\mathrm{Na}^{+} \\
\mathrm{mg} \mathrm{l}^{-1} \\
\end{array}$ & $\begin{array}{c}\mathrm{K}^{+} \\
\mathrm{mg} \mathrm{l}^{-1} \\
\end{array}$ & $\begin{array}{l}\mathrm{SO}_{4}^{2-} \\
\mathrm{mg} \mathrm{l}^{-1} \\
\end{array}$ & $\begin{array}{r}P_{\text {tot }} \\
\mu \mathrm{g} \mathrm{l}^{-1}\end{array}$ & $\begin{array}{c}\mathrm{N}_{\text {tot }} \\
\mathrm{mg} \mathrm{l}^{-1}\end{array}$ \\
\hline 10 Jun 09 & 6.5 & 248 & 7.8 & 2411 & 11.5 & 1.9 & 55.7 & 2.9 & 1.3 & 0.2 & 2.0 & 5.0 & 0.64 \\
\hline 26 Aug 09 & 6.8 & 305 & 7.7 & 2851 & 11.8 & 2.3 & 69.7 & 4.4 & 1.4 & 0.3 & 3.3 & 7.0 & 0.68 \\
\hline 4 Nov 09 & 6.9 & 294 & 7.9 & 2804 & 10.4 & 2.5 & 63.9 & 3.7 & 1.2 & 0.3 & 2.8 & 9.0 & 1.16 \\
\hline 22 Jun 10 & 6.6 & 164 & 8.0 & 2575 & 10.1 & 1.8 & 60.5 & 2.8 & 1.3 & 0.3 & 1.7 & 9.0 & 0.84 \\
\hline 1 Sep 10 & 6.6 & 174 & 7.6 & 2834 & 10.7 & 2.1 & 62.2 & 3.3 & 1.2 & 0.2 & 2.0 & 24.0 & 0.69 \\
\hline 20 Oct 10 & 6.7 & 297 & 7.5 & 3050 & 10.7 & 1.8 & 73.3 & 4.0 & 1.7 & 0.2 & 2.8 & 21.0 & 1.15 \\
\hline $\begin{array}{l}\text { Mean } \\
(n=6)\end{array}$ & 6.7 & 247 & 7.7 & 2754 & 10.9 & 2.1 & 64.2 & 3.5 & 1.4 & 0.2 & 2.5 & 12.5 & 0.9 \\
\hline $\begin{array}{l}\text { Standard } \\
\text { deviation }\end{array}$ & 0.1 & 63 & 0.2 & 226 & 0.7 & 0.3 & 6.4 & 0.6 & 0.2 & 0.0 & 0.6 & 7.9 & 0.2 \\
\hline
\end{tabular}

\section{Microcrustacean assemblages}

A total of 24 species were collected in the Lipnik springs (Table 2). By filtering the water from the temporary and perennial springs, 8 species were collected in the temporary spring 1 (T1), 13 in the temporary spring 2 (2) and 17 in the perennial spring, while the sampling of benthos resulted in 11 species for the spring mouth and 14 species for the spring brook. The most common species frequently occurring in all samples were Bryocamptus dacicus, Elaphoidella phreatica, Mixtacandona sp. A and Mixtacandona sp. B (Tables 2 and 3). Three species were collected only once in the drift from the temporary spring T2 (Nitocrella sp., Speocyclops infernus, Lessinocamptus pivai) and one species only once in the drift from the perennial spring (Bryocamptus rhaeticus). Several species that were abundant in the drift of the perennial spring occurred also in the benthos but were never collected in the drift from the temporary springs (Attheyela wierzejski, Bryocamptus pygmaeus,

Table 2. List of species, their mean densities, and in the brackets the number of samples where species were collected. STY stygobiont (i.e. hypogean species) as defined from the literature (Botosaneanu, 1986).

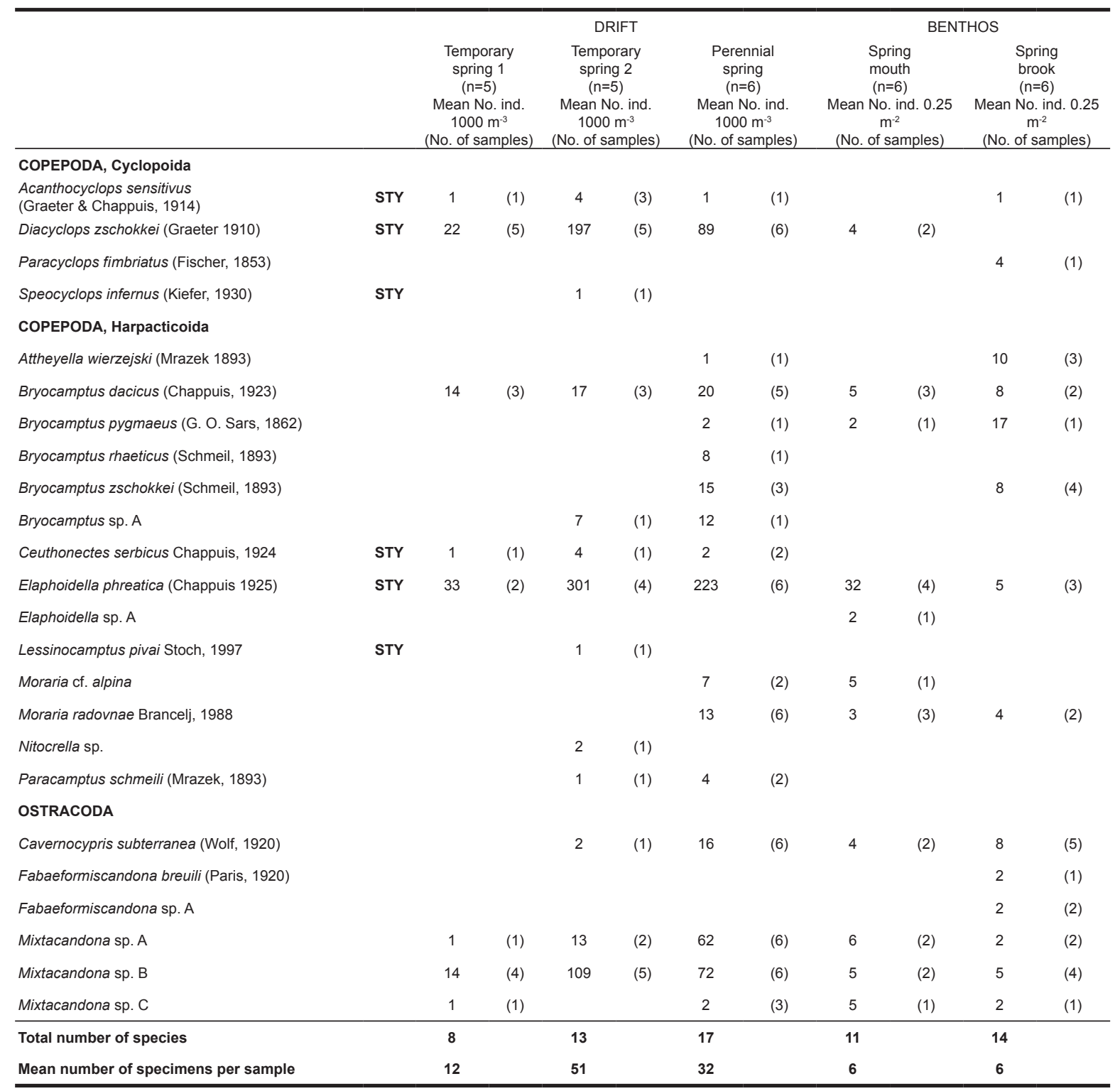


Table 3. Results of the SIMPER analysis indicating the contribution of each species to observed differences among groups of samples. Contrib\% $=$ percentage contribution of the species to overall dissimilarity; Cum $\%$ = cumulative contribution of the species to overall dissimilarity. Species contributing the most to each sample group (spring mouth benthos, spring brook benthos, drift from perennial - P and temporary springs - T1, T2) are in bold.

\begin{tabular}{|c|c|c|c|c|c|c|c|}
\hline \multirow[b]{2}{*}{ Taxon } & \multirow[b]{2}{*}{$\%$ Con } & \multirow[b]{2}{*}{ Cum (\%) } & \multicolumn{3}{|c|}{ DRIFT } & \multicolumn{2}{|c|}{ BENTHOS } \\
\hline & & & $\begin{array}{c}\text { Temporary } \\
\text { spring T1 } \\
\text { Mean } \\
\text { proportion } \\
(\%) \\
\end{array}$ & $\begin{array}{c}\text { Temporary } \\
\text { spring T2 } \\
\text { Mean } \\
\text { proportion } \\
(\%) \\
\end{array}$ & $\begin{array}{l}\text { Perennial } \\
\text { spring } \\
\text { Mean } \\
\text { proportion } \\
(\%) \\
\end{array}$ & $\begin{array}{c}\text { Spring } \\
\text { mouth } \\
\text { Mean } \\
\text { proportion } \\
(\%) \\
\end{array}$ & $\begin{array}{c}\text { Spring } \\
\text { brook } \\
\text { Mean } \\
\text { proportion } \\
(\%)\end{array}$ \\
\hline D. zschokkei & 16.80 & 24.83 & 55.00 & 48.40 & 15.00 & 3.00 & 0.00 \\
\hline E. phreatica & 16.48 & 49.20 & 13.00 & 23.40 & 36.50 & 67.00 & 9.60 \\
\hline M. sp. B & 5.63 & 57.51 & 12.80 & 16.20 & 14.20 & 5.50 & 14.00 \\
\hline B. dacicus & 5.07 & 65.00 & 17.20 & 4.20 & 3.50 & 7.00 & 5.00 \\
\hline B. zschokkei & 3.65 & 70.40 & 0.00 & 0.00 & 3.33 & 0.00 & 16.00 \\
\hline C. subterranea & 3.61 & 75.73 & 0.00 & 0.20 & 2.83 & 3.25 & 15.60 \\
\hline M. sp. A & 3.54 & 80.96 & 0.20 & 1.00 & 13.80 & 3.75 & 1.80 \\
\hline A. wierzejski & 2.88 & 85.21 & 0.00 & 0.00 & 0.17 & 0.00 & 14.20 \\
\hline B. pygmeus & 1.95 & 88.09 & 0.00 & 0.00 & 0.33 & 0.75 & 8.80 \\
\hline M. radovnae & 1.85 & 90.82 & 0.00 & 0.00 & 3.00 & 4.50 & 4.40 \\
\hline B. n.sp. & 1.25 & 92.68 & 0.00 & 3.40 & 2.83 & 0.00 & 0.00 \\
\hline M. sp. C & 0.71 & 93.74 & 0.20 & 0.00 & 0.50 & 2.25 & 1.20 \\
\hline M. alpina & 0.69 & 94.76 & 0.00 & 0.00 & 1.50 & 2.25 & 0.00 \\
\hline F.sp. A & 0.68 & 95.77 & 0.00 & 0.00 & 0.00 & 0.00 & 3.40 \\
\hline F. breuili & 0.56 & 96.60 & 0.00 & 0.00 & 0.00 & 0.00 & 2.80 \\
\hline P. fimbriatus & 0.44 & 97.26 & 0.00 & 0.00 & 0.00 & 0.00 & 2.20 \\
\hline C. serbicus & 0.44 & 97.91 & 1.40 & 0.40 & 0.50 & 0.00 & 0.00 \\
\hline A. sensitivus & 0.33 & 98.39 & 0.20 & 1.00 & 0.00 & 0.00 & 0.60 \\
\hline B. rhaeticus & 0.30 & 98.84 & 0.00 & 0.00 & 1.33 & 0.00 & 0.00 \\
\hline P. schmeili & 0.26 & 99.22 & 0.00 & 0.40 & 0.83 & 0.00 & 0.00 \\
\hline N. sp. & 0.24 & 99.58 & 0.00 & 1.20 & 0.00 & 0.00 & 0.00 \\
\hline E. n.sp. & 0.13 & 99.76 & 0.00 & 0.00 & 0.00 & 0.75 & 0.00 \\
\hline L. pivai & 0.08 & 99.88 & 0.00 & 0.40 & 0.00 & 0.00 & 0.00 \\
\hline S. infernus & 0.08 & 100.00 & 0.00 & 0.40 & 0.00 & 0.00 & 0.00 \\
\hline
\end{tabular}

Bryocamptus zschokkei, Moraria cf. alpina, Moraria radounae). One species was found only in the spring mouth of the perennial spring (Elaphoidella $s p$. A) and three species only in the spring brook benthos (Paracyclops fimbriatus, Fabaeformiscandona breuli, Fabaeformiscandona sp. A). The overall mean number of specimens in the drift samples was the highest in the drift from the temporary spring 2 (T2) and was 51 specimens per $1000 \mathrm{~m}^{3}$ of filtered water. In the benthos, mean densities were similar for both habitats (i.e. 6 specimens per $0.25 \mathrm{~m}^{2}$ ).

Drift densities varied over the time and were the highest in August and November 2009 in all springs (P, T1, T2) (Fig. 2). This is the period when the water from the temporary springs (T1, T2) discharged 60 meters downstream from the usual spring outlet at the same altitude as the perennial spring. In general, the densities were normally higher during the lower volume of the filtered water. The lowest drift densities were in the temporary spring 1 (T1) in June and September 2010 and the highest in the temporary spring 2 (T2) during August 2009.

Non-metric multidimensional scaling (NMDS) (2D, Stress 0.16) indicated a similarity of samples collected from the same sampling sites (Fig. 3). An exception were the samples from the temporary springs (T1, T2) taken in August 2009 and from the temporary spring T2 collected in November 2009 which were in close similarity with the samples from the perennial spring. The most distant were the benthic samples from the spring brook (SB), while the benthos from the spring mouth of the perennial spring and the drift from the same spring mouth were relatively close together. The differences between the sample groups were mostly due to D. zschokkei, E. phreatica, Mixtacandona sp. B, B. dacicus and B. zschokkei (SIMPER, Table 3). D. zschokkei was the indicative species for drift samples from the temporary springs, E. phreatica for drift samples from the perennial spring and spring mouth benthos, and B. zschokkei, C. subterranea, A. wierzejski for the spring brook benthos (Fig. 3). Accordingly, ANOSIM revealed statistically significant differences between all sample groups $(p<0.05)$ but not between the temporary springs 1 and $2(p=0.74)$.

The species accumulation curves (Mao Tau curves) had a higher slope in the case of drift samples than in the case of the benthic ones (Fig. 4). Mao Tau curves reached an asymptote in the case of the benthic
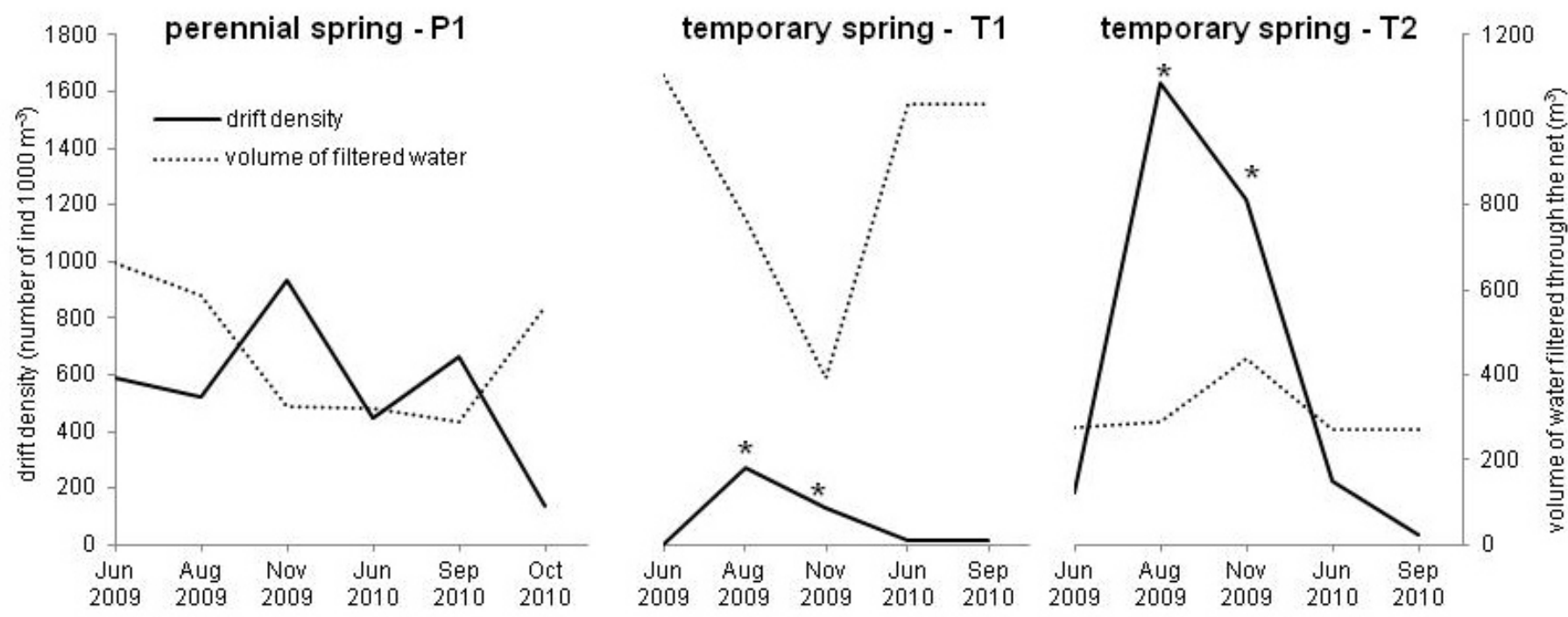

Fig. 2. Diagrams showing variation in drift densities (solid line) and the amount of filtered water (dotted line) over the time in three spring mouths $(\mathrm{P} 1, \mathrm{~T} 1, \mathrm{~T} 2)$. The sampling occasions when the water from the temporary springs discharged downstream from the usual site are marked with an asterisk. The data from 22nd Oct 2010 for the temporary springs were not considered due to an accidental displacement of sampling nets during sampling. 


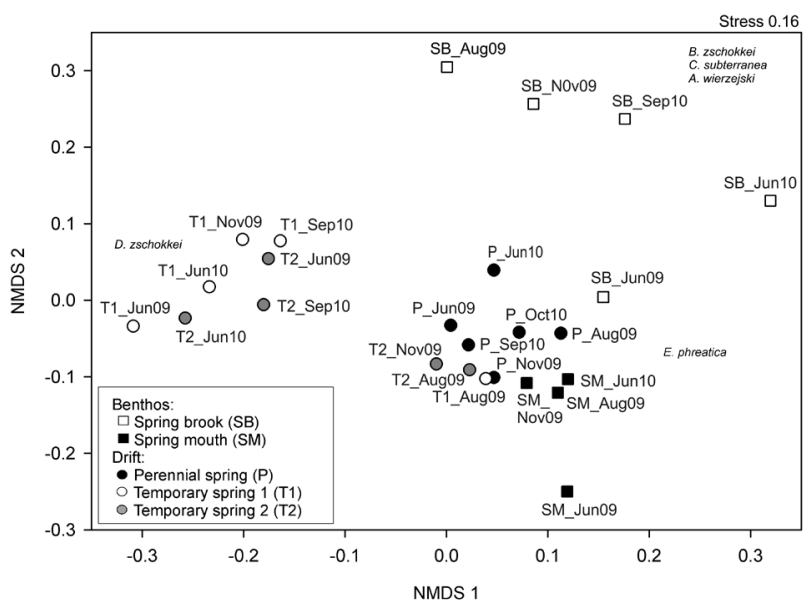

Fig. 3. NMDS diagram representing the position of the samples in $2 D$ space. Data on species abundances were transformed to their relative proportions (\%) in the samples. A Bray-Curtis index of similarity was used as a distance matrix. The sample code consists of the name of the sample (for benthos: SM - spring mouth; SB - spring brook; for drift: T1, T2 - temporary springs, $\mathrm{P}$ - perennial spring), and month and year of sampling occasion (J - June, A - August; S- September, $\mathrm{N}$ - November; 09 - 2009, 10 - 2010). The most abundant species characteristic for each sample group as calculated by SIMPER are plotted to the diagram.

samples from the spring mouth and spring brook and in the case of drift samples from the perennial spring. The estimated mean numbers of species using the Chao2 equation were 10.5 species for the spring mouth benthos, 15.6 species for the spring brook benthos, and 19.1 species for drift from the perennial spring and 16 and 37.5 species for drift from the temporary springs 1 and 2 , respectively (Table 4).

\section{DISCUSSION}

\section{Habitat heterogeneity and species richness}

The spatial and temporal variation in drift densities and species composition was high indicating strong dependence of drift on actual water level conditions (low/high-water levels) and most probably diverse origin of the water discharging from the studied karstic outlets. Geomorphology and hydrology of karstic systems are known to be spatially and temporally highly complex (Kaufmann, 2003). The precipitation regime, development and structure of epikarst, infiltration rates, and underground runoff in the vadose zone and draining from the phreatic zone determine the hydrological characteristics of karstic outlets (Mangin, 1994). Vervier and Gibert (1991) demonstrated that in the case of the vadose zone, the species composition of the fauna collected by sampling of drift from karstic outlets depends greatly on the precipitation regime and hydrological conditions. After high precipitation rates a flush of water outwashes species that would not be drifted out at a normal hydrological condition (Gibert, 1986). Accordingly, the timing of the sampling can greatly affect the results obtained by collecting drift. In this study, drift densities were generally lower during a larger volume of filtered water which occurred during high-water level conditions.

The attempts to interpret the origin of drifting species (the epikarst and vadose zones versus the phreatic zone) and to describe the characteristics of "epikarst/vadose" and "phreatic" assemblages needs to be tentative due to the fact that an indirect sampling method (filtering of the spring water) was applied and that at certain hydrological periods water discharging from the karstic outlets at the interface of both zones can be a result of mixing water originating from both zones or even from epikarst (Doctor et al., 2006). For several species that were collected from the perennial and occasionally from the temporary springs there exist different explanations: either 1) the species actually inhabit both zones or 2) the lifting of groundwater table and mixing of water from the two zones together with possible active movements of animals from the phreatic zone upwards resulted in the occurrence in both springs. Most likely, the species that are constantly present in the drift from both types of outlets (temporary, perennial) inhabit both zones; whereas that species that just occasionally occur exclusively in the drift from the temporary springs originate in the epikarst zone. Background knowledge on the ecology and habitat preferences of some species can be helpful in identifying the origin of the water. For example, Speocyclops infernus is a typical epikarst species that was commonly collected
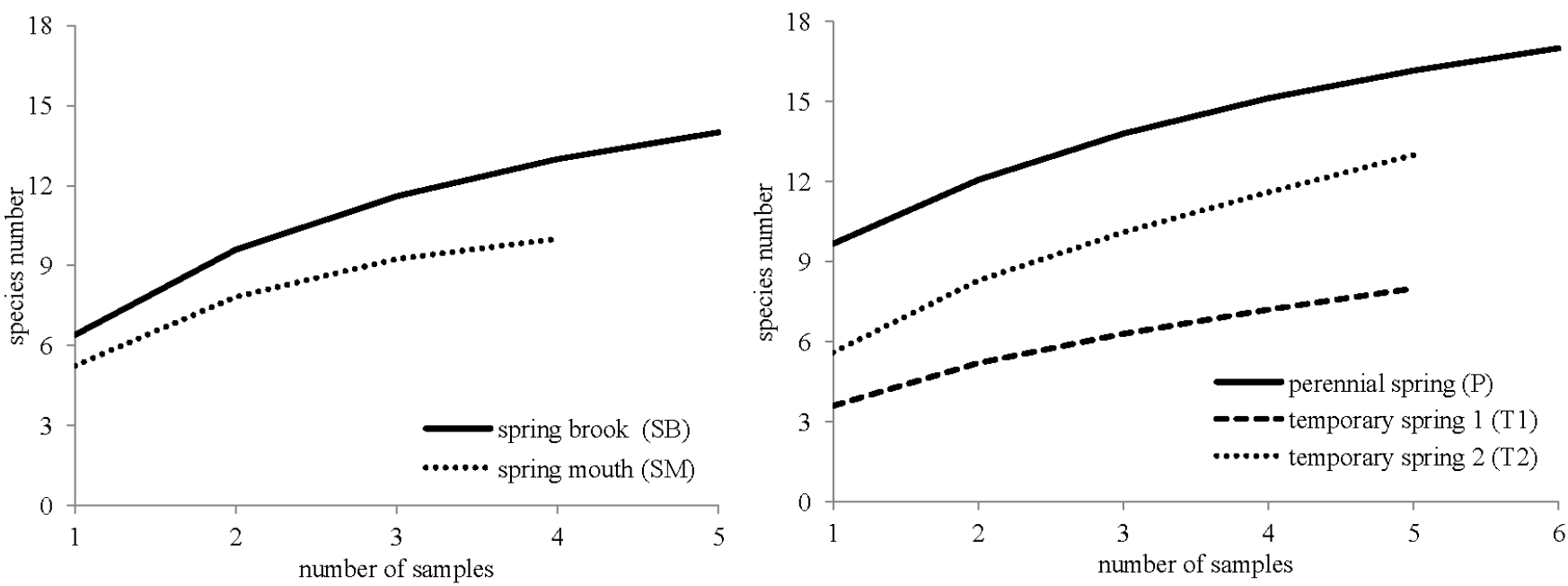

Fig. 4. Mao Tau species accumulation curves for drift samples from the temporary and perennial springs (left), and for benthic samples from the spring mouth and spring brook discharging from perennial spring (right). 
Table 4. Mean Chao2 with $95 \%$ confidence intervals (lower and upper bounds) for five sample groups.

\begin{tabular}{llccc}
\hline & & $\begin{array}{l}\text { Chao2 } \\
\text { Lower } \\
\text { Bound }\end{array}$ & $\begin{array}{c}\text { Chao2 } \\
\text { Mean }\end{array}$ & $\begin{array}{l}\text { Chao2 } \\
\text { Upper } \\
\text { Bound }\end{array}$ \\
\hline Benthos & Spring mouth & 10.0 & 10.5 & 15.8 \\
& Spring brook & 14.2 & 15.6 & 25.7 \\
\multirow{2}{*}{ Drift } & Perennial spring & 17.3 & 19.1 & 31.6 \\
& Temporary spring 1 & 9.0 & 16.0 & 72.8 \\
& Temporary spring 2 & 16.6 & 37.5 & 180.2 \\
\hline
\end{tabular}

from dripping water in the caves (Brancelj, 2002; Papi and Pipan, 2011) and its presence in the sample confirms that the water flows from the epikarst.

Despitetheabovementioned constraints, adistinction in drift densities and species richness and composition between the perennial and temporary springs can give us an insight into hydrological dynamics of an Alpine karstic aquifer and corresponding outlets as well as indicate the characteristics of the hypogean fauna from the two zones (epikarst/vadose zone; phreatic zone). The fauna collected by filtering the water from the perennial spring most likely represents the fauna from the phreatic zone which is characterized by typical species such as Elaphoidella phreatica. This species is known from previous studies to live in the karstic phreatic zone and also in the porous aquifer (Mori and Brancelj, 2008; Galassi et al., 2013). On the contrary, the samples from the temporary springs (with the exception of the sampling during the low flow when the temporary springs discharged at the same altitude as the perennial spring), were lower in densities and species numbers, the dominating species was Diacyclops zschokkei and occasionally contained the typical fauna known to inhabit the epikarst and vadose zone such as Lessinocamptus pivai. The latter is the typical species known to live in the epikarst and vadose zone (Galassi et al., 2013).

Close correspondence between habitat diversity and species diversity is one of the central tenets in ecology (Larned, 2012). Karstic aquifers are hydrologically and geomorphologically highly heterogeneous, but with a clear distinction between the vadoze zone (including the uppermost layer of epikarst) and the phreatic zone (Gibert et al., 1994). The main differences between the epikarst and vadose zones and the phreatic zone are their physical structure, hydrological characteristics and strength of hydrological connectivity with surface waters and adjacent aquifers (Gibert et al., 1994). The epikarst/vadose zone is highly fractured with mostly vertical but also lateral channels, sometimes comprising also larger caves where water flows fast during precipitation and also quickly disappears, while the phreatic zone is less densely fractured and channels are perennially filled with water (Gibert et al., 1994). In the epikarst and vadose zones, a higher water flow in the conductive subsystem during high rain is most probably detrimental to fauna which avoids this subsystem and mostly occupies the adjacent capacitive zone where water flow is lower and retention of organic matter higher (Galassi et al., 2009a). In contrast, the phreatic zone lacks harsh fast flowing conduits and drying/rewetting phases and therefore encompasses better conditions for the hypogean fauna which occurs here in higher abundances. Stoch (1995) pointed out the importance of environmental stability and predictability of habitats for differences in species richness. If some environmental parameters fluctuate in a regular and predictable way, organisms may evolve some degree of dependence and specialization on temporary patterns of resource availability, enhancing diversity. The phreatic zone is hydrologically much more stable than the epikarst and vadose zones with their drying/ rewetting cycles. Consequently, habitat fragmentation and processes of speciation are more intensive in the latter (Galassi et al., 2009b). Di Lorenzo et al. (2005) suggested that the species occurrence may be explained by hydrological connections between hypogean and surface waters. This was confirmed also in this study where many of the species occurring in the spring benthos were present also in the drift of the perennial spring indicating constant migration of surface species into hypogean waters. In contrast, the benthic species rarely occurred in the temporary springs but the species abundantly present in the drift of the perennial spring were often collected also in the drift from the temporary springs, what is indicative of interconnectivity of the two zones. Galassi et al. (2009b) observed a higher regional distributional rarity of the species from the vadose zone compared to that in the phreatic zone, which was not the case in this study where only one site was investigated. Here the species richness was the highest in the drift from the perennial spring. However, the species richness estimator Chao2 indicated that total species richness would be more than twice higher than observed in the temporary springs that are presumably mainly fed from the epikarst and vadose zones.

Sampling effort and sampling methodology can produce different species richness estimations (Hancock and Boulton, 2009). The latter authors demonstrated that a single sampling collected $30-87 \%$ of the total species. In this study, the first sampling collected 54 $\%$ of total species in the perennial spring and $45 \%$ and $43 \%$ of all species in the two temporary springs (T1, T2), respectively. The species accumulation curves did not reach asymptote in the drift of the temporary springs indicating that additional sampling would result in higher species richness. The fauna in the epikarst and vadose zones is much scarcer than in the phreatic zone and hence an intensive repeated sampling is needed here to obtain total species numbers. A comparison of species composition in the samples revealed some similarity between the samples from drift of the perennial spring and the benthos of the spring mouth, but still only $41 \%$ of species were in common. A similar fact was shown in France where sampling in caves resulted in few species of copepods, while filtering of the water from a karstic outlet on several occasions gave 21 species of harpacticoids, with 3-200 specimens per $\mathrm{m}^{3}$ (Rouch, 1984). The sampling of the spring mouth benthos does not seem to be an accurate method for estimating the species richness and community composition in the vadose zone, but it can be a proxy for it in the phreatic zone. 


\section{Characterization of microcrustacean assemblages}

The sampling of drift from karstic outlets at the interface of the vadose and phreatic zones of an alpine karstic aquifer revealed high species richness of microcrustaceans with altogether 20 species recorded in the drift, 16 being copepods. This is surprisingly high since alpine karst has been known previously as species poor due to glaciations and low water temperatures. For example, the study from the northern Italy resulted in 19 microcrustacean species that were collected in 16 high altitude caves in Trentino (Stoch, 2000) and Papi and Pipan (2011) collected 2 copepod species in the epikarst of an alpine cave over 7 sampling occasions. In this study, 14 species were collected from two temporary springs and 13 from the perennial one. One of the reasons for high species numbers are repeated samplings ( 5 to 6 times in two years). Repeated sampling is a must for a good assessment of hypogean species richness (Rouch and Danielopol, 1997; Schneider and Culver, 2004). The other reason is the fact that the sampling in this study was carried out at the contact zone between the vadose and the phreatic zone which is in contrast to other alpine studies where epikarst and caves located within the vadose zone were investigated. The former two studies were focused on the alpine epikarst and consequently resulted in less species than this study where the alpine temporary spring most probably fed from the epikarst and vadose zones and occasionally also from the phreatic zone were sampled. The number of copepod species from this study is similar to that in other studies from the Dinaric region where 12 copepods were collected in the epikarst of a non-alpine (Dinaric) cave on eight sampling occasions (Brancelj, 2002), and 11 to 14 copepods in the caves of the Postojnska jama cave system (Slovenia) (Pipan and Brancelj, 2004; Pipan, 2005; Pipan and Culver, 2007a, b). To summarize, the high species richness comparable to that in the Dinaric areas in the studied aquifer is firstly due to the mode of sampling (repeated filtering of water in karstic outlets), and secondly due to a highly developed underground system of fissures (availability of space) and close connection with the phreatic zone and further on with the porous aquifer of the Radovna river (interconnectivity).

The microcrustacean assemblages were composed of several ecological groups: 1) abundant species frequently occurring in all samples; 2) abundant species frequently occurring in all samples, but not in the drift from temporary springs; 3) rare species occurring exclusively in the drift from the temporary springs; 4) rare species most probably restricted to the benthos of the spring mouth; and 5) species exclusively from the spring brook benthos (Table 5). In general, a typical epikarst microcrustacean assemblage is comprised of harpacticoid Lessinocamptus, Paramorariopsis, Parastenocaris genus and the cyclopid species Speocyclops infernus (Brancelj, 2002; Pipan, 2005; Brancelj, 2009; Galassi et al., 2009b). Previously, Speocyclops infernus was shown to be widespread over broader geographical areas in the epikarst and vadose zones (Pipan, 2005; Brancelj, 2009; Papi and Pipan, 2011), while Lessinocamptus pivai was reported to be collected only from one karstic site (the vadose zone) in the northern Italy (Stoch, 1997). E. phreatica, accompanied by Attheyella wierzejski, Bryocamptus rhaeticus and Moraria radovnae, was frequently found in alpine springs (Bottazzi et al., 2008; Mori and Brancelj, 2008) and alluvial habitats (Pesce and Galassi, 1986; Malard et al., 2003). The species is considered common in southern and central Europe, inhabiting predominantly porous aquifers (as indicated by its name phreatica) (Illies, 1978). On the other hand, little is known about ecology and distribution of the ostracod genus Mixtacandona in Slovenia, the third most abundant species in the Lipnik springs. Mixtacandona is exclusively hypogean genus with an array of species inhabiting karstic as well as alluvial aquifers (Rogulj and Danielopol, 1993; Mori and Meisch, 2012). In terms of biogeography, the species differ from those inhabiting Dinaric karst. Most probably the species that are widely distributed in the Alps, such as Elaphoidella phreatica are post-glacial colonizers, while the species with a restricted distribution mostly in the epikarst colonized the area during Pliocene and they survived glaciations in deep aquifers (Stoch, 2000; Sambugar et al., 2008).

\section{CONCLUSIONS}

The study demonstrated that alpine karstic groundwaters previously assumed as species poor environments can be rich in the hypogean fauna. The study of drift from the temporary and perennial springs brings new insights into its temporal variability due to variability in hydrology (low/high water levels). There is an indication that during high water levels drift densities are lower and species typical for epikarst/vadose zone occur in the drift, while during low water levels mainly fauna characteristics for phreatic zone occur in the drift. A comparison of the samples from the drift of the perennial spring and the samples from the spring mouth benthos revealed a distinct species composition indicating that filtering of the spring water is most likely a more accurate method for the assessment of the hypogean species richness and characterization of its species composition. However, this hypothesis needs to be tested on a larger scale and needs to include also the sampling in the caves and boreholes.

Table 5. Classification of the species on the basis of their occurrence across habitats (drift of temporary and perennial springs, benthos in the spring mouth and spring brook).

\begin{tabular}{llll}
\hline abundant in all samples & $\begin{array}{l}\text { abundant in all samples but NOT present } \\
\text { in the drift from the temporary springs }\end{array}$ & $\begin{array}{l}\text { exclusively in the drift from the } \\
\text { temporary springs }\end{array}$ & $\begin{array}{l}\text { exclusively in the benthos of the } \\
\text { spring mouth }\end{array}$ \\
\hline Bryocampus dacicus & Bryocamptus zschokkei & $\begin{array}{l}\text { Speocyclops infernus } \\
\text { spring brook }\end{array}$ & Bryocamptus rhaeticus \\
Elaphoidella phreatica & Moraria radovnae & Lessinocamptus pivai & Moraria alpina \\
Mixtacandona sp. B & Cavernocypris subterranea & Nitocrella sp. & Fabaeformiscandona breuili \\
& Mixtacandona sp. A & & Fabaeformiscandona sp. A \\
\hline
\end{tabular}




\section{ACKNOWLEDGEMENTS}

The authors are grateful to Dr. Irena Bertoncelj, Tina Leskošek and Basak $\mathrm{Oz}$ for the help in the field, Andreja Jerebic for technical support in the laboratory and Andrej Kapla and Allen Wei Liu for the graphical support. The authors acknowledge financial support from the state budget by the Slovenian Research Agency (Z1-2213 and P1-0255). The study was partly funded by the EU project Alp-Water-Scarce (Alpine Space programme, 2008-2011).

\section{REFERENCES}

Bottazzi E., Bruno M.C., Mazzini M., Pieri V. \& Rossetti G., 2008 - First report on Copepoda and Ostracoda (Crustacea) from northern Apenninic springs ( $N$. Italy): a faunal and biogeographical account. Journal of Limnology, 67: 56-63.

http://dx.doi.org/10.4081/jlimnol.2008.56

Botosaneanu L., 1986 - Stygofauna Mundi. A faunistic, distributional, and ecological synthesis of the world fauna inhabiting subterranean waters. Brill, Leiden, $740 \mathrm{p}$.

Brancelj A., 2002 - Microdistribution and high diversity of Copepoda (Crustacea) in a small cave in central Slovenia. Hydrobiologia, 477: 59-72.

http://dx.doi.org/10.1023/A:1021043014879

Brancelj A., 2009 - Fauna of an unsaturated karstic zone in Central Slovenia: two new species of Harpacticoida (Crustacea: Copepoda), Elaphoidella millennii n. $s p$. and E. tarmani n. sp., their ecology and morphological adaptations. Hydrobiologia, 621: 85-104. http://dx.doi.org/10.1007/s10750-008-9634-3

Buser S., 1987 - Osnouna Geološka Karta SFRJ 1:100 000. Zvezni Geološki Zavod, Beograd.

Chao A., 1987 - Estimating the population size for capturerecapture data with unequal catchability. Biometrics, 43: 783-791. http://dx.doi.org/10.2307/2531532

Clesceri L.S., Greenberg A.E. \& Eaton A.D., 1998 Standard methods for the examination of water and wastewater. APHA, AWWA, WEF, Baltimore, 1162 p.

Colwell R.K., 2009 - EstimateS: Statistical estimation of species richness and shared species from samples. Version 8.2. User's guide and application published at: http://purl.oclc.org/estimates.

Colwell R.K., Mao C.X. \& Chang J., 2004 - Interpolating, extrapolating, and comparing incidence-based species accumulation curves. Ecology, 85: 2717-2727. http://dx.doi.org/10.1890/03-0557

Cristian E. \& Spötl C., 2010 - Karst geology and cave fauna of Austria: a concise review. International Journal of Speleology, 39: 71-90. http://dx.doi.org/10.5038/1827-806X.39.2.3

Culver D.C. \& Sket B., 2000 - Hotspots of subterranean biodiversity in caves and wells. Journal of Cave and Karst Studies, 62: 11-17.

Di Lorenzo T., Stoch F., Fiasca B., Gattone E., De Laurentiis P., Ranalli F. \& Galassi D.M.P., 2000 - Environmental quality of deep groundwater in the Lessinian Massif (Italy): signposts for sustainability. In: Gibert J. (Ed.) - World subterranean biodiversity. Proceedings of an international symposium held December 8 through 10 2004 Villeurbanne, France. Lyon, University Claude Bernard of Lyon 1 and CNRS: 115-125.

Doctor D.H., Alexander Jr E.C., Petrič M., Kogovšek J., Urbanc J., Lojen S. \& Stichler W., 2006 - Quantification of karst aquifer discharge components during storm events through end-member mixing analysis using natural chemistry and stable isotopes as tracers. Hydrogeology Journal, 14: 1171-1191.

http://dx.doi.org/10.1007/s10040-006-0031-6
Dole-Olivier M.J., Malard F., Martin D., Lefebure T. \& Gibert J., 2009a - Relationships between environmental variables and groundwater biodiversity at the regional scale. Freshwater Biology, 54: 797-813. http://dx.doi.org/10.1111/j.1365-2427.2009.02184.x Dole-Olivier M.J., Castellarini F., Coineau N., Galassi D.M.P., Martin P., Mori N., Valdecasas A. \& Gibert J., 2009b - Towards an optimal sampling strategy to assess groundwater biodiversity: comparison across six European regions. Freshwater Biology, 54: 777-796. http://dx.doi.org/10.1111/j.1365-2427.2008.02133.x

Einsle U., 1993 - Crustacea: Copepoda: Calanoida und Cyclopoida. Gustav Fischer Verlag, Stuttgart, 208 p.

Fišer C. \& Zagmajster M., 2009 - Cryptic species from cryptic space: the case of Niphargus fongi $s p . n$. (Amphipoda, Niphargidae). Crustaceana, 82: 593-614. http://dx.doi.org/10.1163/156854009X407704

Fong D.W. \& Culver D.C., 1996 - Fine-scale biogeographic differences in the crustacean fauna of a cave system in West Virginia, USA. Hydrobiologia, 287: 29-37.

http://dx.doi.org/10.1007/BF00006894

Galassi D.M.P., Huys R. \& Reid J.W., 2009a - Diversity, ecology and evolution of groundwater copepods. Freshwater Biology, 54: 691-708. http://dx.doi.org/10.1111/j.1365-2427.2009.02185.x

Galassi D.M.P., Stoch F., Fiasca B., Di Lorenzo T. \& Gattone E., 2009b - Groundwater biodiversity patterns in the Lessinian Massif of northern Italy. Freshwater Biology, 54: 830-847.

http://dx.doi.org/10.1111/j.1365-2427.2009.02203.x

Galassi D.M.P., Stoch F. \& Brancelj A., 2013 Dissecting copepod diversity at different spatial scales in southern European groundwater. Journal of Natural History, 47: 821-840.

http://dx.doi.org/10.1080/00222933.2012.738834

Gams I., 2003 - Kras $v$ Sloveniji v prostoru in času. ZRC, Ljubljana, 293 p.

Gibert J., 1986 - Ecologie d'un systeme karstique jurassien. Mémoires de Biospéologie, 13:1-379.

Gibert J. \& Deharveng L., 2002 - Subterranean ecosystems: a truncated functional biodiversity. Bioscience, 52: 473-481.

http://dx.doi.org/10.1641/0006-3568(2002)052[0473:SE ATFB]2.0.CO;2

Gibert J., Stanford J.A., Dole-Olivier M.-J. \& Ward J.V., 1994 - Basic attributes of groundwater ecosystems and prospects for research. In: Gibert J., Danielopol D.L. \& Stanford J.A. (Eds.) - Groundwater Ecology. New York: Academic Press: 7-40.

Gotelli N. \& Colwell R.K., 2001 - Quantifying biodiversity: Procedures and pitfalls in the measurement and comparison of species richness. Ecology Letters, 4: 379-391. http://dx.doi.org/10.1046/j.1461-0248.2001.00230.x

Hahn H.J. \& Fuchs A., 2009 - Distribution patterns of groundwater communities across aquifer types in southwestern Germany. Freshwater Biology, 54: 848-860. http://dx.doi.org/10.1111/j.1365-2427.2008.02132.x

Hancock P.J. \& Boulton A.J., 2009 - Sampling groundwater fauna: efficiency of rapid assessment methods tested in bores in eastern Australia. Freshwater Biology, 54: 902-917.

http://dx.doi.org/10.1111/j.1365-2427.2007.01878.x

Hammer Ø., Harper D.A.T. \& Ryan P.D., 2001 - PAST: Paleontological statistics software package for education and data analysis. Palaeontologia Electronica, 4: 1-9.

Illies J., 1978 - Limnofauna Europeae. Gustav Fischer Verlag, Stuttgart, $552 \mathrm{p}$.

Janetzky W., Enderle R. \& Noodt W., 1996 - Crustacea: Copepoda: Gelyelloida und Harpacticoida. Gustav Fischer Verlag, Stuttgart, 288 p. 
Kanduč T., Mori N., Kocman D., Stibilj V. \& Grassa F., 2012 - Hydrogeochemistry of Alpine springs from North Slovenia: Insights from stable isotopes. Chemical Geology, 300-301: 40-54. http://dx.doi.org/10.1016/j.chemgeo.2012.01.012

Kaufmann G., 2003 - Modeling unsaturated flow in an evolving karst aquifer. Journal of Hydrology, 276: 53-70.

Larned S.T., 2012 - Phreatic groundwater ecosystems: research frontiers for freshwater ecology. Freshwater Biology, 57: 885-906.

http://dx.doi.org/10.1111/j.1365-2427.2012.02769.x

Leruth R., 1939 - La biologie du domaine souterrain et la faune cavernicole de Belgique. Memoires du Musee royal d'histoire naturelle de Belgique, 87: 1-507.

Malard P., Mathieu J., Reygrobellet J.-L. \& Lafont M., 1996 - Biomonitoring groundwater contamination. Aplication to a karst area in Southern France. Aquatic Sciences, 58: 158-187. http: / /dx.doi.org/10.1007/BF00877113

Malard F., Galassi D., Lafont M., Dolédec S. \& Ward J.W., 2003 - Longitudinal patterns of invertebrates in the hyporheic zone of a glacial river. Freshwater Biology, 48: $1709-1725$. http://dx.doi.org/10.1046/j.1365-2427.2003.01118.x

Mangin A., 1994 - Karst hydrogeology. In: Gibert J., Danielopol D.L. \& Stanford J.A. (Eds.) - Groundwater Ecology. London: Academic Press: 44-67.

Mao C.X., Colwell R.K. \& Chang J., 2005 - Estimating the species accumulation curve using mixtures. Biometrics, 61: 433-411. http://dx.doi.org/10.1111/j.1541-0420.2005.00316.x

Meisch C., 2000 - Crustacea: Ostracoda. Spektrum Akademischer Verlag, Heildelberg, 522 p.

Mori N. \& Brancelj A., 2008 - Distribution and habitat preferences of species within the genus Elaphoidella Chappuis, 1929 (Crustacea: Copepoda: Harpacticoida) in Slovenia. Zoologische Anzeiger, 247: 85-94. http://dx.doi.org/10.1016/j.jcz.2007.01.002

Mori N. \& Meisch C., 2012 - Contribution to the knowledge on the distribution of Recent free-living freshwater ostracods (Podocopida, Ostracoda, Crustacea) in Slovenia. Natura Sloveniae, 14: 5-22.

Papi F. \& Pipan T., 2011 - Ecological studies of an epikarst community in Snežna jama na planini Arto - an ice cave in north central Slovenia. Acta Karsologica, 40: 505-513.

Pesce G.L. \& Galassi D.M.P., 1986 - A new species of Elaphoidella from groundwater of Sardinia, and first record of Elaphoidella cvetkae Petkovski from Italy (Crustacea; Harpacticoida). Bollettino di Zoologia, 10: 221-225.

Petrič, M., 2004 - Alpine karst waters in Slovenia. Acta Carsologica, 33: 11-24.

Pipan T., 2005 - Epikarst - a promising habitat. ZRC Publishing, Ljubljana, $101 \mathrm{p}$.

Pipan T. \& Brancelj A., 2004 - Distribution patterns of Copepods (Crustacea: Copepoda) in percolation water of the Postojnska jama Cave system (Slovenia). Zoological Studies, 43: 206-210.

Pipan T. \& Culver D.C., 2007a - Regional species richness in an obligate subterranean dwelling fauna - epikarst copepods. Journal of Biogeography, 34: 854-861.

http://dx.doi.org/10.1111/j.1365-2699.2006.01667.x

Pipan T. \& Culver D.C., 2007b - Copepod distribution as an indicator of epikarst system connectivity. Hydrogeology Journal, 15: 817-822. http://dx.doi.org/10.1007/s10040-006-0114-4

Rogulj B. \& Danielopol D., 1993 - Three new Mixtacandona (Ostracoda) species from Croatia, Austria and France. Vie et Milieu, 43: 145-154.
Rouch R., 1968 - Contribution a la connaissance des harpacticides hypoges (Crustaces - Copepodes). Annales de Speleologie, 23: 5-167.

Rouch R., Juberthie-Jupeau L. \& Juberthie C., 1968 - Essai d'étude du peuplement de la zone noyée d'un karst. Annales de Spéléologie, 23: 717-733.

Rouch R., 1984 - Les structures de peuplement des Harpacticides dans l'écosystème karstique. Crustaceana, 7: 360-368.

Rouch R. \& Danielopol D.L., 1997 - Species richness of microcrustacea in subterranean freshwater habitats. Comparative analysis and aproximate evaluation. Internationale Revue der gesamten Hydrobiologie, 82: 121-145. http://dx.doi.org/10.1002/iroh.19970820202

Sambugar B., Ferrarese U., Martinez-Ansemil E., Stoch F., Tomasin G. \& Zullini A., 2008 - The groundwater fauna of Piani Eterni karstic area (Dolomiti Bellunesi National Park, Southern Limestone Alps, Italy) and its zoogeographic significance. Subterranean Biology, 6: 67-76.

Schneider K. \& Culver D.C., 2004 - Estimating subterranean species richness using intensive sampling and rarefaction curves in a high density cave region in West Virginia. Journal of Cave and Karst Studies, 66: 39-45.

Sket B., 1999 - The nature of biodiversity in hypogean waters and how it is endangered. Biodiversity and Conservation, 8: 1319-1338. http://dx.doi.org/10.1023/A:1008916601121

Sket B. \& Bole J., 1981 - Organizmi kot indikatorji podzemeljskih vodnih povezav/Organisms as indicators of subterranean water connections. Naš Krš, 10-11: 243-252.

Sket B., Trontelj P. \& Žagar C., 2004 - Speleobiological characterization of the epikarst and its hydrological neighborhood: its role in dispersion of biota, its ecology and vulnerability. In: Jones W.K., Culver D.C. \& Herman J.S. (Eds.) - Epikarst. Proceedings of the symposium held October 1 through 4, 2003 Shepherdstown, West Virginia, USA. Washington, Karst Waters Institute Special Publication 9: 104-113.

Smart C., 2004 - Alpine karst. In: Gunn J. (Ed.) Encyclopedia of Caves and Karst Science. Taylor and Francis, New York, London, 31-33.

Stoch F., 1995 - The ecological and historical determinants of crustacean diversity in groundwaters, or: Why are there so many species? Mémoires de Biospéologie, 22: 139-160.

Stoch F., 1997 - A new genus and two new species of Canthocamptidae (Copepoda, Harpacticoida) from caves in northern Italy. Hydrobiologia, 350: 49-61. http://dx.doi.org/10.1023/A:1003072813906

Stoch F., 2000 - Indagini sulla fauna acquatica delle grotte del Trentino (Italia Settentrionale). Studi Trentini di Scienze Naturali, Acta Biologica, 74: 117-132.

Stoch F., Artheau M., Brancelj A., Galassi D.M.P. \& Malard P., 2009 - Biodiversity indicators in European ground waters: towards a predictive model of stygobiotic species richness. Freshwater Biology, 54: 745-755. http://dx.doi.org/10.1111/j.1365-2427.2008.02143.x

Vervier P. \& Gibert J., 1991 - Dynamics of surface water/ groundwater ecotones in a karstic aquifer. Freshwater Biology, 26: 241-250. http://dx.doi.org/10.1111/j.1365-2427.1991.tb01733.x

Williams P.W., 2008 - The role of the epikarst in karst and cave hydrogeology: a review. International Journal of Speleology, 37: 1-10. http://dx.doi.org/10.5038/1827-806X.37.1.1 